\title{
Efficacy and safety of antiviral treatment for COVID-19 from evidence in studies of SARS- CoV-2 and other acute viral infections: a systematic review and meta-analysis
}

\author{
Wei Liu PhD, Pengxiang Zhou MPharm, Ken Chen MPharm, Zhikang Ye MPharm, Fang Liu MSc, \\ Xiaotong Li MSc, Na He MSc, Ziyang Wu BSc, Qi Zhang MSc, Xuepeng Gong PhD, Qiyu Tang BSc, Xin Du BSc, \\ Yingqiu Ying MSc, Xiaohan Xu MSc, Yahui Zhang BSc, Jinyu Liu PhD, Yun Li MSc, Ning Shen MD, \\ Rachel J. Couban MA, Quazi I. Ibrahim MSc, Gordon Guyatt MD MSc, Suodi Zhai BSc
}

Cite as: CMAJ 2020 July 6;192:E734-44. doi: 10.1503/cmaj.200647; early-released June 3, 2020

See related article at www.cmaj.ca/lookup/doi/10.1503/cmaj.200648

\begin{abstract}
BACKGROUND: Antiviral medications are being given empirically to some patients with coronavirus disease 2019 (COVID-19). To support the development of a COVID-19 management guideline, we conducted a systematic review that addressed the benefits and harms

direct evidence from COVID-19 studies was not available, we included indirect evidence from studies of severe acute respiratory syndrome (SARS) and Middle East respiratory syndrome (MERS) for efficacy outcomes and other acute respiratory viral infections for safety outcomes.
\end{abstract} of 7 antiviral treatments for COVID-19.

METHODS: We searched MEDLINE, Embase, Cochrane Central Register of Controlled Trials (CENTRAL), PubMed and 3 Chinese databases (CNKI, WANFANG and SinoMed) through Apr. 19, medRxiv and Chinaxiv through Apr. 27, and Chongqing VIP through Apr. 30, 2020. We included studies of ribavirin, chloroquine, hydroxychloroquine, umifenovir (arbidol), favipravir, interferon and lopinavir/ritonavir. If
RESULTS: In patients with nonsevere COVID-19 illness, the death rate was extremely low, precluding an important effect on mortality. We found only very low-quality evidence with little or no suggestion of benefit for most treatments and outcomes in both nonsevere and severe COVID-19. An exception was treatment with lopinavir/ritonavir, for which we found low-quality evidence for a decrease in length of stay in the intensive care unit (risk difference $5 \mathrm{~d}$ shorter, 95\% confidence interval $[\mathrm{Cl}] 0$ to $9 \mathrm{~d}$ ) and hospital stay (risk difference $1 \mathrm{~d}$ shorter, 95\% $\mathrm{Cl} 0$ to $2 \mathrm{~d}$ ). For safety outcomes, evidence was of low or very low quality, with the exception of treatment with lopinavir/ ritonavir for which moderate-quality evidence suggested likely increases in diarrhea, nausea and vomiting.

INTERPRETATION: To date, persuasive evidence of important benefit in COVID-19 does not exist for any antiviral treatments, although for each treatment evidence has not excluded important benefit. Additional randomized controlled trials involving patients with COVID-19 will be needed before such treatments can be administered with confidence.

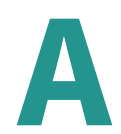
s of Apr. 30, 2020, coronavirus disease 2019 (COVID-19) $^{1}$ has resulted in more than 3 million cases and more than 210000 deaths worldwide. ${ }^{2}$ The World Health Organization (WHO) has declared the COVID-19 outbreak a pandemic. The pathogen, severe acute respiratory syndrome coronavirus 2 (SARS-CoV-2), ${ }^{3}$ is a novel Betacoronavirus that shares a phylogenetic similarity to SARS-CoV (about 79\%) and Middle East respiratory syndrome (MERS)-CoV (about 50\%).,5
Many clinical trials of potential COVID-19 treatments are underway, but current strategies for treatment are based to a considerable extent on preclinical studies and previous experiences from SARS and MERS. ${ }^{6}$ Clinicians have administered a number of antiviral treatments to patients with COVID19. ${ }^{7}$ Optimal decision-making regarding these agents requires systematic summaries of the best available evidence about antiviral agents. 
We provide a systematic review conducted to support a clinical practice guideline that offers recommendations to address currently used antiviral treatments (i.e., ribavirin, chloroquine, hydroxychloroquine, umifenovir, favipiravir, interferon and lopinavir/ritonavir) for COVID-19. ${ }^{8}$ Because remdesivir was unavailable at the time the panel determined the scope of the guideline, we did not include it in our review; however, results for the first randomized controlled trials (RCTs) of remdesivir are now available. ${ }^{9}$ The review includes RCTs and observational studies in patients with COVID-19, in patients with SARS and MERS, and in patients with influenza.

\section{Methods}

\section{Study design and data sources}

We adhered to the Preferred Reporting Items for Systematic Reviews and Meta-Analysis (PRISMA) Statement. Appendix 1 (available at www.cmaj.ca/lookup/suppl/doi:10.1503/cmaj.200647/-/ DC1) presents the protocol of this systematic review. Appendix 2 (available at www.cmaj.ca/lookup/suppl/doi:10.1503/ cmaj.200647/-/DC1) presents our detailed search strategy for 2 independent searches. We searched MEDLINE, Embase, the Cochrane Central Register of Controlled Trials (CENTRAL), PubMed and 3 Chinese databases (China National Knowledge Infrastructure [CNKI], Wanfang and SinoMed) through Apr. 19, 2020, and medRxiv and Chinaxiv preprints through Apr. 27, 2020. We also searched another Chinese database (Chongqing VIP Information) through Apr. 30, 2020. We used search terms that comprised a combination of SARS, MERS, COVID-19 and drugs of interest, as developed by an experienced medical librarian (R.C.).

Owing to concerns about inadequate evidence for safety, we performed an expanded search for safety outcomes in other acute respiratory infections that included PubMed, Embase and CENTRAL through Mar. 19, 2020. The search terms included combinations of drugs of interest, respiratory infectious diseases and terms specific for identifying RCTs. We also sought other eligible studies from reference lists of eligible published articles for both of our searches.

We considered a study eligible if it met the following criteria: patients enrolled in the trial had a diagnosis of COVID-19, SARS, MERS or other acute respiratory infectious diseases (Appendix 1); the trial involved antiviral treatments of interest (i.e., ribavirin, chloroquine, hydroxychloroquine, umifenovir, favipiravir, interferon and lopinavir/ritonavir); the trial evaluated efficacy (i.e., mortality, mechanical ventilation rate, length of stay in the intensive care unit [ICU], length of hospital stay, virologic outcomes, disease progression rate or relief of symptoms) or safety (symptomatic and serious adverse events) outcomes; and the study type was RCT, cohort study or case-control study. We did not exclude by language.

We included the best available evidence using the following hierarchy: COVID-19 RCTs; COVID-19 observational studies with adjusted analysis; RCTs involving SARS and MERS; observational studies in SARS and MERS with adjusted analysis; for safety outcomes only, RCTs addressing acute respiratory infectious diseases other than SARS and MERS (Appendix 1); observational studies without adjusted analysis; and studies comparing the drugs of interest with another antiviral agent. For each outcome, when studies from the higher categories provided evidence of higher quality than studies in lower categories, we included only the higher-quality evidence. Because of communication and time costs of informing the guideline panel of evidence summary changes, we no longer included evidence identified after Apr. 19, 2020, with very low quality that were unlikely to change the recommendations.

Pairs of reviewers independently screened titles and abstracts and reviewed the full texts of potentially eligible studies to determine eligibility. They resolved any disagreements by discussion. Two reviewers independently extracted data, including names of authors, publication year, study country or region, study design, patient population, sample size for each group, age, sex, percentage of patients who were critically ill, interventions and comparison regimen, and outcomes. Reviewers resolved any disagreement by discussion.

Two reviewers independently assessed risk of bias for each study using a modification of the Cochrane criteria for RCTs, a modification of the Newcastle-Ottawa instrument for cohort studies and an instrument developed specifically for case-control studies. ${ }^{10}$ Reviewers judged each criterion as definitely or probably low risk of bias, or probably or definitely high risk of bias, and resolved any disagreements by discussion or, if necessary, by consultation with a third reviewer.

The Grading of Recommendations, Assessment, Development, and Evaluation (GRADE) approach informed the assessment of quality of evidence for each of our outcomes (Table 1). ${ }^{13}$ Mortality, mechanical ventilation and length of stay in the ICU were assessed only for the population of patients with severe illness, whereas we assessed rate of disease progression and symptom-based outcomes for only the nonsevere population. For efficacy outcomes, we rated down 1 level for indirectness if evidence came from studies involving patients with SARS or MERS. For safety outcomes, we did not rate down for indirectness for patients with SARS or MERS; however, we rated down 1 level for other acute respiratory infections. We present evidence using the GRADE Summary of Findings tables.

\section{Table 1: Definitions of quality of evidence ${ }^{13}$}

Quality Definition

High We are very confident that the true effect lies close to that of the estimate of the effect.

Moderate We are moderately confident in the effect estimate. The true effect is likely to be close to the estimate of the effect, but there is a possibility that it is substantially different.

Low Our confidence in the effect estimate is limited. The true effect may be substantially different from the estimate of the effect.

Very low We have very little confidence in the effect estimate. The true effect is likely to be substantially different from the estimate of effect. 
Statistical analysis

Using numbers of events and patients in RCTs and cohort studies, and adjusted relative estimates reported by original observational studies, we conducted our meta-analysis with Review Manager (version 5.3). Mantel-Haenszel random-effect models provided methods to calculate risk ratios (RRs) for RCTs and for cohort studies of dichotomous outcomes. We used DerSimonian and Laird inverse variance random-effect models to pool adjusted RRs and odds ratios (ORs). For studies that made their original data set available, we conducted a multiple regression analysis to calculate relative estimates.

Our target populations were patients with nonsevere and severe COVID-19 illness. We adhered to the WHO definition of pneumonia for severe COVID-19: fever or suspected respiratory infection, plus 1 of the following: respiratory rate $>30$ breaths/min, severe respiratory distress, or peripheral oxygen saturation $\left(\mathrm{SpO}_{2}\right) \leq 93 \%$ on room air. ${ }^{11}$ We identified the baseline risk of each outcome in patients with severe and nonsevere COVID-19 from published studies, choosing the most representative populations. We applied relative effects to baseline risks to estimate risk differences. When no patient in the control group experienced an event, the incidence and associated 95\% confidence interval $(\mathrm{Cl})$ in the intervention group provided the estimated risk difference. Where hazard ratios (HRs) were provided, we estimated risk of an event in the intervention group from HRs and risk in the control group. ${ }^{12}$

\section{Ethics approval}

Ethics approval was not required for this systematic review.

\section{Results}

Figure 1 and Appendix 3 (available at www.cmaj.ca/lookup/suppl/ doi:10.1503/cmaj.200647/-/DC1) show flow charts for the study. We included 19 studies that were conducted in China $(n=11 ; 7$ of the studies are preprints $\left.{ }^{15,17,18,24,27,28,32}\right)$, Saudi Arabia $(n=2)$, Singapore $(n=1)$, United States $\left(n=1\right.$ [preprint] $\left.{ }^{19}\right)$, France $(n=1)$ and Canada $(n=1) .{ }^{14-32}$ Two of these studies were multiregional. ${ }^{16,29}$ Seven studies used an RCT design, 11 used a cohort design and 1 used a casecontrol design. The studies enrolled patients with COVID-19 $(n=12)$, MERS $(n=2)$, SARS $(n=4)$ and influenza $(n=1)$. The interventions used in the studies included ribavirin $(n=3)$, hydroxychloroquine $(n=5)$, favipiravir $(n=3)$, interferon $(n=3)$, lopinavir/ritonavir $(n=2)$, umifenovir $(n=1)$, ribavirin and interferon $(n=1)$, and umifenovir and lopinavir/ritonavir $(n=1)$. Table 2 presents characteristics of the included studies. We did not find any eligible studies that addressed the use of chloroquine.

Among 7 RCTs, $4^{15,18,21,26}$ were open label and rated down for lack of blinding ( 2 of these studies were preprints ${ }^{15,18}$ ). One RCT did not blind patients or physicians (preprint). ${ }^{17}$ We determined that the other 2 RCTs ${ }^{16,28}$ were low risk of bias ( 1 of these RCTS is a preprint ${ }^{28}$ ). Figure 2 presents the risk-of-bias assessment for RCTs. Table 3 and Table 4 present the risk-of-bias assessment for observational studies.

A large epidemiologic study in China that involved 173 patients with severe COVID-19 provided our baseline mortality estimate of $10.4 \% .^{33}$ Table 5 presents baseline risk data for all outcomes.

\section{Ribavirin}

\section{Efficacy}

Two retrospective cohort studies 29,30 that enrolled 1334 patients with SARS (mixed severity of illness) provided mortality estimates. One of these studies was conducted in Hong Kong and Canada, which was analyzed separately, ${ }^{29}$ and the other was in Singapore. ${ }^{30}$ Pooled results suggested uncertain effects of treatment using ribavirin on mortality (OR $0.83,95 \% \mathrm{Cl} 0.49$ to 1.41 ) (Appendix 4, Supplementary Figure 1, available at www.cmaj.ca/ lookup/suppl/doi:10.1503/cmaj.200647/-/DC1). One case-control study that involved 51 patients with MERS ${ }^{22}$ (mixed severity of illness) provided similar findings (OR $0.66,95 \% \mathrm{Cl} 0.04$ to 12.36 ). Both SARS and MERS studies provided very low-quality evidence for effects of treatment using ribavirin on mortality in patients with severe COVID-19 illness (Appendix 5, Supplementary Table 2, available at www.cmaj.ca/lookup/suppl/doi:10.1503/ cmaj.200647/-/DC1).

\section{Safety}

One retrospective cohort study that involved 306 patients ${ }^{31}$ with SARS and mixed severity of illness reported that ribavirin increased the incidence of anemia (defined as a decrease in hemoglobin level of $20 \mathrm{~g} / \mathrm{L}$; OR $3.00,95 \% \mathrm{Cl} 1.77$ to 5.16) and bradycardia (defined as a heart rate $<55$ beats/min; OR 2.30, $95 \% \mathrm{Cl} 1.21$ to 4.20 ). Because both outcomes were surrogates (i.e., anemia for symptomatic anemia and bradycardia for symptomatic bradycardia), we rated down for indirectness and judged quality of evidence as very low (Appendix 5, Supplementary Tables 1 and 2).

\section{Hydroxychloroquine}

\section{Efficacy}

Three $\operatorname{RCTs}^{17,18,21}$ ( 2 of these RCTs are preprints ${ }^{17,18}$ ) that involved 240 patients with nonsevere and 2 patients with severe COVID-19 illness compared treatment with hydroxychloroquine and treatment without hydroxychloroquine, providing very low-quality evidence of minimal effects on viral clearance at day 14 (RR 0.98, 95\% Cl 0.89 to 1.07; Appendix 4, Supplementary Figure 2), progression from nonsevere to severe illness (RR 0.96, 95\% Cl 0.10 to 9.66; Appendix 4, Supplementary Figure 3) or clinical recovery at day 7 (RR $1.10,95 \% \mathrm{Cl}$ 0.44 to 2.77$).{ }^{17}$ Hydroxychloroquine might result in a shorter duration of fever (mean difference [MD] $1 \mathrm{~d}$ shorter, $95 \% \mathrm{Cl}$ 0.36 to $1.64 \mathrm{~d}$ shorter; very low-quality evidence; Appendix 5, Supplementary Table 3).

In addition, 2 observational studies (preprints) ${ }^{19,20}$ that enrolled patients with COVID-19 (181 with severe and 255 with mixed-severity illness) provided very low-quality evidence for effects of hydroxychloroquine on mortality (RR $1.48,95 \% \mathrm{Cl}$ 0.42 to 5.24; Appendix 4, Supplementary Figure 4, and Appendix 5, Supplementary Table 4). One of these studies also reported inconclusive results of the use of hydroxychloroquine while patients were receiving mechanical ventilation (Appendix 5, Supplementary Table 4). ${ }^{19}$ 


\section{Safety}

Two RCTs ${ }^{18,21}$ ( 1 of these studies is a preprint ${ }^{18}$ ) that enrolled 178 patients with nonsevere and 2 patients with severe COVID-19 illness reported that no patient had diarrhea in the treatment group without hydroxychloroquine; however, $10.6 \%(95 \% \mathrm{Cl}$ $4.0 \%$ to $17.1 \%$ ) of patients in the hydroxychloroquine treatment group had diarrhea (low-quality evidence; Appendix 5, Supplementary Tables 3 and 4). An RCT that involved 62 patients with
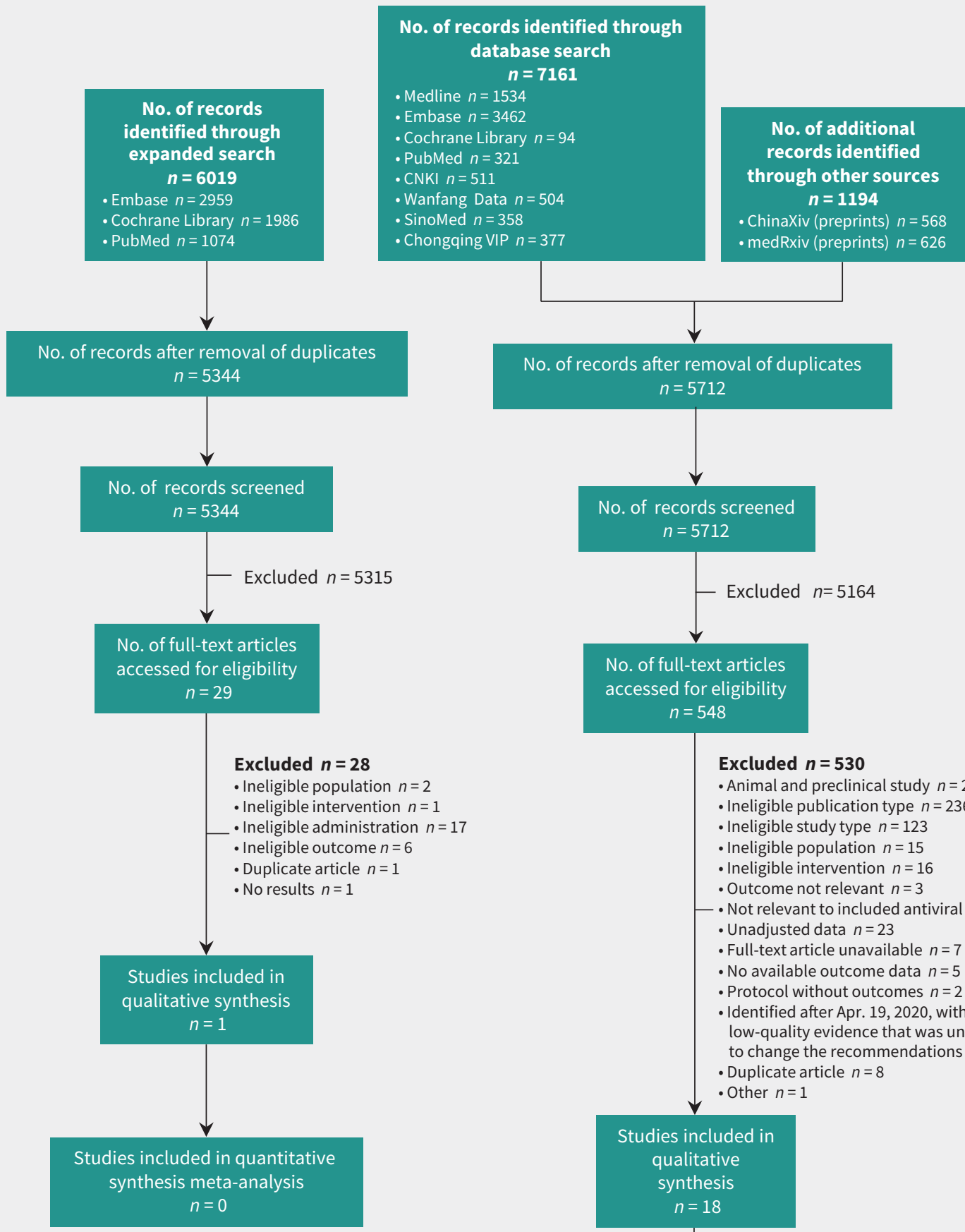

No. of records after removal of duplicates $n=5712$
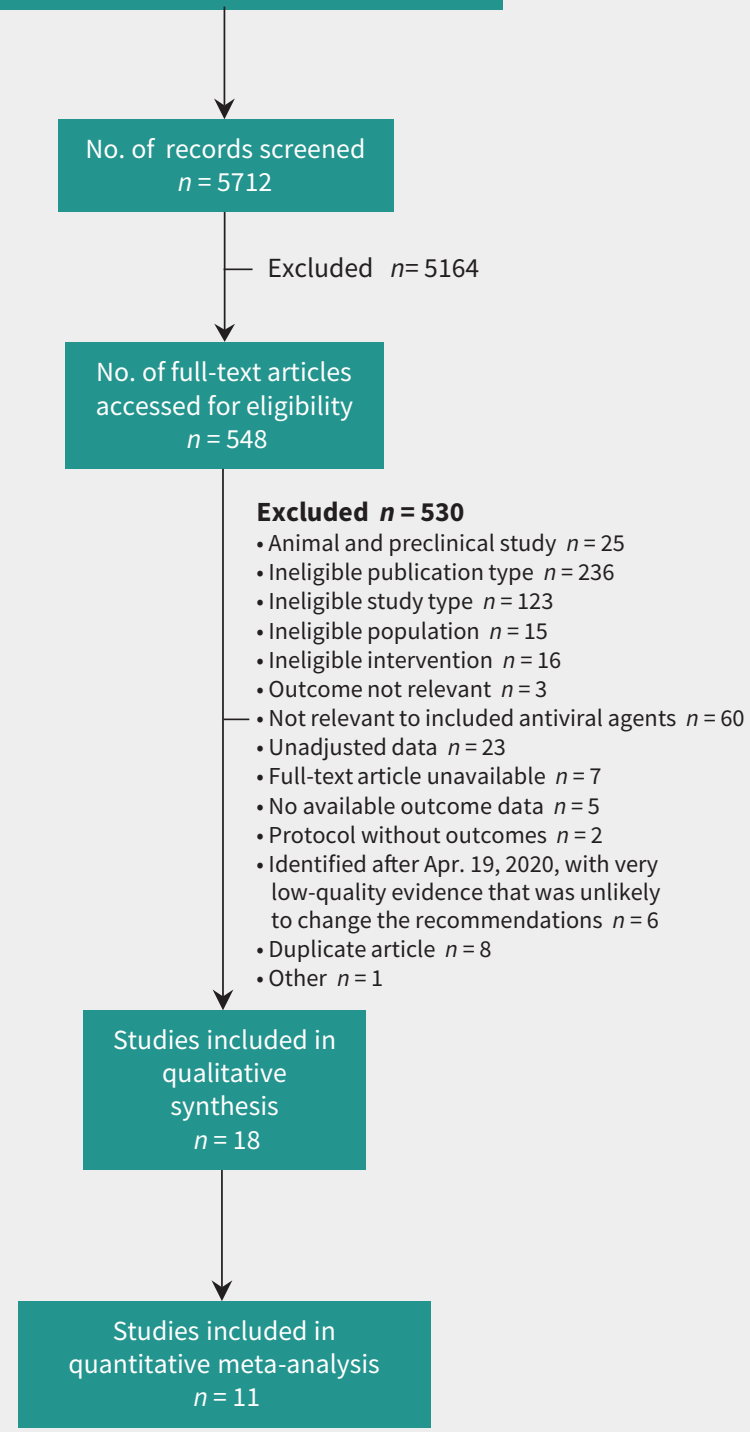

Figure 1: Flow chart for the determination of included studies. CNKI = China National Knowledge Infrastructure. 
nonsevere COVID-19 illness (preprint) ${ }^{17}$ reported an incidence of headache or rash in the intervention group of $3.2 \%(95 \% \mathrm{Cl} 0 \%$ to $9.4 \%$ ), with none of these events in the control group. An RCT (preprint) ${ }^{18}$ that enrolled 148 patients with nonsevere and 2 with severe COVID-19 reported an incidence of both nausea and blurred vision in $1.4 \%(95 \% \mathrm{Cl} 0 \%$ to $4.2 \%)$ of patients and an incidence of vomiting in $2.9 \%(95 \% \mathrm{Cl} 0 \%$ to $6.8 \%)$; none of these events occurred in the control group. The quality of evidence for headache, rash, nausea, vomiting and blurred vision was very low (Appendix 5, Supplementary Tables 3 and 4).

\section{Table 2 (part 1 of 2): Characteristics of the included studies}

\begin{tabular}{|c|c|c|c|c|c|c|c|c|c|}
\hline Reference & Study intervention & $\begin{array}{l}\text { Antiviral agent } \\
\text { comparison }\end{array}$ & $\begin{array}{l}\text { Study } \\
\text { design }\end{array}$ & Country & $\begin{array}{l}\text { Participant } \\
\text { population }\end{array}$ & $\begin{array}{l}\text { No. of } \\
\text { participants }\end{array}$ & $\begin{array}{c}\text { Age, } \\
\text { mean } \pm S D^{*}\end{array}$ & $\begin{array}{c}\text { Percentage } \\
\quad \text { of } \\
\text { population } \\
\text { who were } \\
\text { male }\end{array}$ & $\begin{array}{c}\text { Percentage } \\
\text { of } \\
\text { population } \\
\text { with } \\
\text { severe } \\
\text { disease }\end{array}$ \\
\hline \multicolumn{10}{|c|}{ Favipiravir v. lopinavir/ritonavir } \\
\hline Cai et al., $2020^{14}$ & $\begin{array}{l}\text { Favipiravir } 1600 \mathrm{mg} \text { po } \\
\text { b.i.d. on day } 1 \text { and } \\
600 \mathrm{mg} \text { po b.i.d. on } \\
\text { days } 2-14 \text { plus } \\
\text { interferon- } \alpha \text { ( } 60 \mu \mathrm{g} \\
\text { b.i.d.) by aerosol } \\
\text { inhalation }\end{array}$ & $\begin{array}{l}\text { Lopinavir/ritonavir } \\
\text { ( } 200 \mathrm{mg} / 50 \mathrm{mg}) \\
500 \mathrm{mg} \text { po b.i.d. on } \\
\text { days } 1-14 \text { plus } \\
\text { interferon- } \alpha 60 \mu \mathrm{g} \\
\text { b.i.d. by aerosol } \\
\text { inhalation }\end{array}$ & Cohort & China & $\begin{array}{l}\text { Nonsevere } \\
\text { COVID-19 }\end{array}$ & 80 & $\begin{array}{c}47.0 \\
(35.8-61.0) \dagger\end{array}$ & 43.8 & 0 \\
\hline \multicolumn{10}{|c|}{ Favipiravir versus umifenovir } \\
\hline $\begin{array}{l}\text { Chen et al., } \\
2020^{15} \ddagger\end{array}$ & $\begin{array}{l}\text { Favipiravir } 1600 \mathrm{mg} \text { po } \\
\text { b.i.d. on day } 1 \text { and } \\
600 \mathrm{mg} \text { po b.i.d. for } \\
7-10 \mathrm{~d} \S\end{array}$ & $\begin{array}{l}\text { Umifenovir ( } 200 \mathrm{mg} \text { ) } \\
\text { po t.i.d. for } 7-10 \mathrm{~d}\end{array}$ & $\mathrm{RCT}$ & China & $\begin{array}{l}\text { COVID-19 with } \\
\text { mixed severity }\end{array}$ & 236 & NR & 46.6 & 11.4 \\
\hline \multicolumn{10}{|c|}{ Favipiravir versus no favipiravir } \\
\hline $\mathrm{MDVI}^{16}$ & $\begin{array}{l}\text { Favipiravir } 1200 \text { mg po } \\
\text { b.i.d. for } 1 \mathrm{~d} \text {, followed } \\
\text { by } 800 \mathrm{mg} \text { po b.i.d. for } \\
4 \mathrm{~d}\end{array}$ & Placebo & RCT & $\begin{array}{l}\text { Multiple } \\
\text { countries }\end{array}$ & $\begin{array}{l}\text { Influenza with } \\
\text { unspecified } \\
\text { severity }\end{array}$ & 386 & $\begin{array}{c}42.7 \\
(20.0-80.0) \emptyset\end{array}$ & 45.3 & NR \\
\hline \multicolumn{10}{|c|}{ Hydroxychloroquine versus no hydroxychloroquine } \\
\hline $\begin{array}{l}\text { Chen et al., } \\
2020^{17} \ddagger\end{array}$ & $\begin{array}{l}\text { Hydroxychloroquine } \\
(200 \mathrm{mg}) \text { po b.i.d. for } 5 \mathrm{~d}\end{array}$ & No hydroxychloroquine & $\mathrm{RCT}$ & China & $\begin{array}{l}\text { Nonsevere } \\
\text { COVID-19 }\end{array}$ & 62 & $44.7 \pm 15.3$ & 46.8 & 0 \\
\hline $\begin{array}{l}\text { Tang et al., } \\
2020^{18} \ddagger\end{array}$ & $\begin{array}{l}\text { Hydroxychloroquine: } \\
\text { loading dose of } \\
1200 \text { mg daily for } 3 \mathrm{~d} \\
\text { followed by a } \\
\text { maintainence dose of } \\
800 \text { mg daily for } \\
\text { remaining treatment } \\
\text { days (total treatment } \\
\text { duration: } 2 \text { wk for } \\
\text { patients with mild/ } \\
\text { moderate disease or } \\
3 \text { wh for patients with } \\
\text { severe disease) }\end{array}$ & No hydroxychloroquine & $\mathrm{RCT}$ & China & $\begin{array}{l}\text { COVID-19 with } \\
\text { mixed severity }\end{array}$ & 150 & $46.1 \pm 14.7$ & 54.7 & 1.3 \\
\hline $\begin{array}{l}\text { Magagnoli et } \\
\text { al., } 2020^{19} \ddagger\end{array}$ & $\begin{array}{l}\text { Hydroxychloroquine } \\
\text { dose not mentioned }\end{array}$ & No hydroxychloroquine & Cohort & US & $\begin{array}{l}\text { COVID-19 with } \\
\text { mixed severity }\end{array}$ & 255 & NR & 100.0 & NR \\
\hline $\begin{array}{l}\text { Mahevas et al., } \\
2020^{20} \ddagger\end{array}$ & $\begin{array}{l}\text { Hydroxychloroquine } \\
600 \mathrm{mg} / \mathrm{d}\end{array}$ & No hydroxychloroquine & Cohort & France & $\begin{array}{l}\text { COVID-19 with } \\
\text { mixed severity }\end{array}$ & 181 & $\begin{array}{c}60.0 \\
(52.0-68.0) \dagger\end{array}$ & 71.1 & NR \\
\hline \multicolumn{10}{|c|}{ Hydroxychloroquine plus interferon versus interferon alone } \\
\hline $\begin{array}{l}\text { Chen et al., } \\
2020^{21}\end{array}$ & $\begin{array}{l}\text { Hydroxychloroquine } \\
\text { ( } 400 \text { mg) po daily for } 5 \mathrm{~d} \\
\text { plus interferon- } \alpha \text { by } \\
\text { aerosol inhalation } \\
\text { ( } 80.0 \% \text { of patients used } \\
\text { umifenovir) }\end{array}$ & $\begin{array}{l}\text { Interferon- } \alpha \text { by aerosol } \\
\text { inhalation ( } 66.7 \% \text { of } \\
\text { patients used } \\
\text { umifenovir and } 13.3 \% \\
\text { used lopinavir/ } \\
\text { ritonavir) }\end{array}$ & $\mathrm{RCT}$ & China & $\begin{array}{l}\text { Nonsevere } \\
\text { COVID-19 }\end{array}$ & 30 & $48.6 \pm 4.1$ & 70.0 & 0 \\
\hline \multicolumn{10}{|c|}{ Interferon versus no interferon, ribavirin versus no ribavirin } \\
\hline $\begin{array}{l}\text { Al Ghamdi et } \\
\text { al., } 2016^{22}\end{array}$ & $\begin{array}{l}\text { A: interferon- } \alpha \\
\text { B: interferon- } \beta \\
\text { C: ribavirin }\end{array}$ & $\begin{array}{l}\text { A: no interferon- } \alpha \\
\text { B: no interferon- } \beta \\
\text { C: no ribavirin }\end{array}$ & $\begin{array}{l}\text { Case- } \\
\text { control }\end{array}$ & $\begin{array}{l}\text { Saudi } \\
\text { Arabia }\end{array}$ & $\begin{array}{l}\text { MERS with } \\
\text { mixed severity }\end{array}$ & 51 & $\begin{array}{c}54.0 \\
(36.5-58.0) \dagger\end{array}$ & 78.4 & 37.3 \\
\hline \multicolumn{10}{|c|}{ Interferon plus ribavirin versus ribavirin alone } \\
\hline $\begin{array}{l}\text { Shalhoub et al., } \\
2015^{23}\end{array}$ & $\begin{array}{l}\text { Interferon- } \alpha 2 \mathrm{a}(180 \mu \mathrm{g}) \\
\text { by sc injection weekly; } \\
\text { interferon- } \beta 1 \mathrm{a}(44 \mu \mathrm{g}) \\
\text { by sc injection } 3 \text { times } \\
\text { per week plus ribavirin } \\
\text { ( } 2 \mathrm{~g} \text { loading dose) po } \\
\text { followed by } 600 \mathrm{mg} \\
\text { q. } 12 \mathrm{~h}\end{array}$ & $\begin{array}{l}\text { Ribavirin ( } 2 \text { g loading } \\
\text { dose) po followed by } \\
600 \mathrm{mg} \mathrm{q} .12 \mathrm{~h}\end{array}$ & Cohort & $\begin{array}{l}\text { Saudi } \\
\text { Arabia }\end{array}$ & $\begin{array}{l}\text { MERS with } \\
\text { mixed severity }\end{array}$ & 32 & $\begin{array}{c}60.0 \\
(42.0-73.0) \dagger\end{array}$ & 56.0 & NR \\
\hline
\end{tabular}




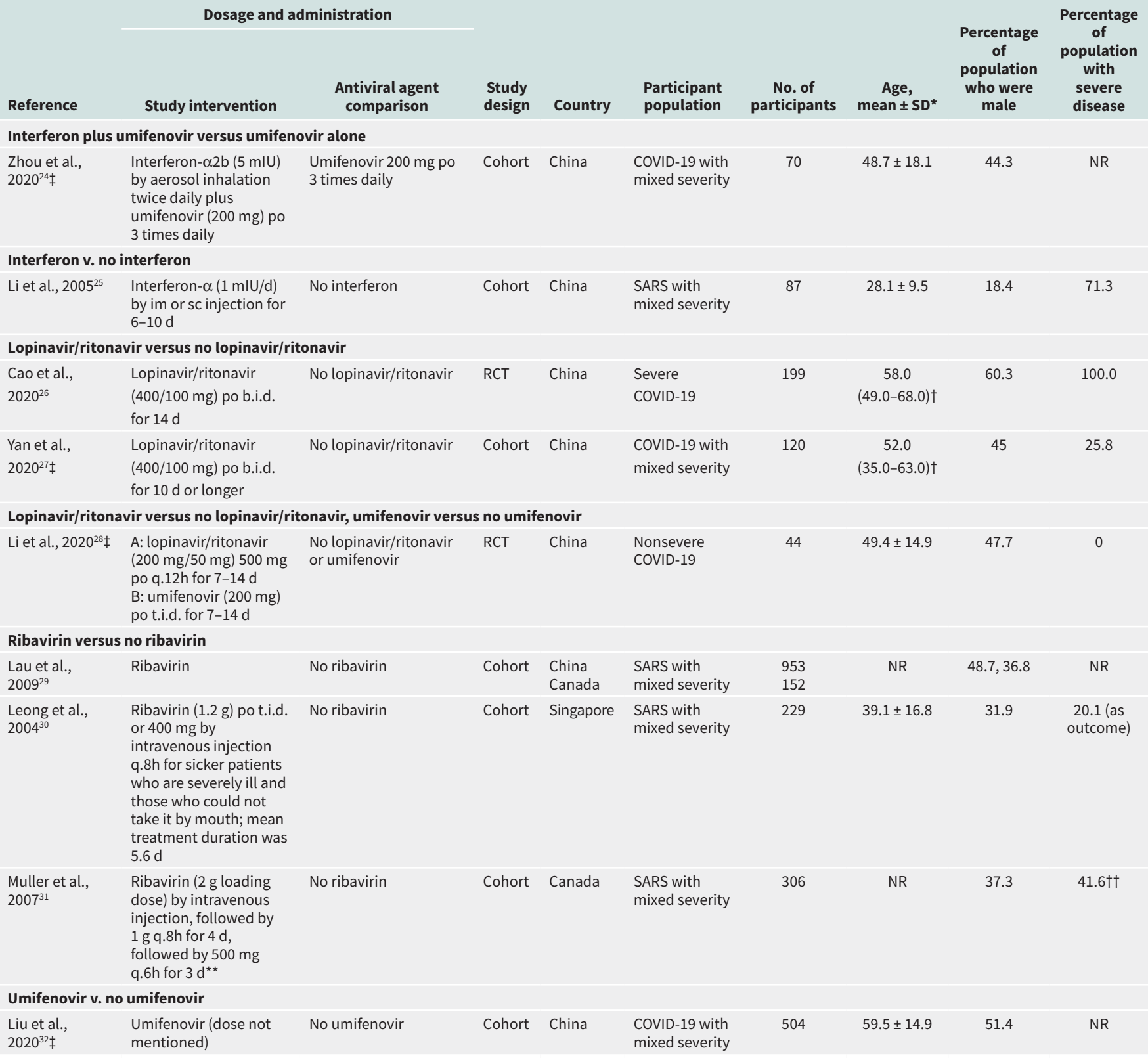

Note: b.i.d. = twice a day, COVID-19= coronavirus disease 2019, im = intramuscular, IQR = interquartile range, MERS = Middle East respiratory syndrome, NR = not reported, po = by mouth, q. $6 \mathrm{~h}=$ every 6 hours, q. $8 \mathrm{~h}=$ every 8 hours, q. $12 \mathrm{~h}=$ every 12 hours, RCT $=$ randomized controlled trial, $\mathrm{SARS}=$ severe acute respiratory syndrome, sC $=$ subcutaneous, $\mathrm{SD}=\mathrm{standard}$ deviation, t.i.d. $=3$ times per day. *Unless stated otherwise.

†Median (IQR).

$\ddagger$ Preprint.

§The course of treatment in both groups was 7-10 days. If necessary, the treatment time could have been extended to 10 days according to the judgment of researchers.

IMean (range).

** Only 155 of 183 participants received this treatment regimen; the other 28 patients received several lower-dose treatment regimens.

††Calculated from the baseline characteristic, admission oxygen saturation $<95 \%$.

\section{Umifenovir}

\section{Efficacy}

One RCT that enrolled 23 patients with nonsevere COVID-19 illness (preprint) ${ }^{28}$ provided limited evidence of uncertain effects of treatment using umifenovir on viral clearance at day 14, cough alleviation at day 7 , fever at day 7 and progression to severe illness (Appendix 5, Supplementary Table 5). With additional indirectness, this trial reported even lower-quality evidence for delayed viral clearance in patients with severe COVID-19 illness (Appendix 5, Supplementary Table 6). An observational study in Wuhan, China, that enrolled 504 patients with mixed severities of COVID-19 illness (preprint) ${ }^{32}$ reported a large decrease in mortality among those who received umifenovir (OR 0.18, 95\% $\mathrm{Cl} 0.08$ to 0.45 ). However, we found the quality of evidence to be very low because of the observational study design and suboptimal adjustment for disease severity (Appendix 5, Supplementary Table 6). 


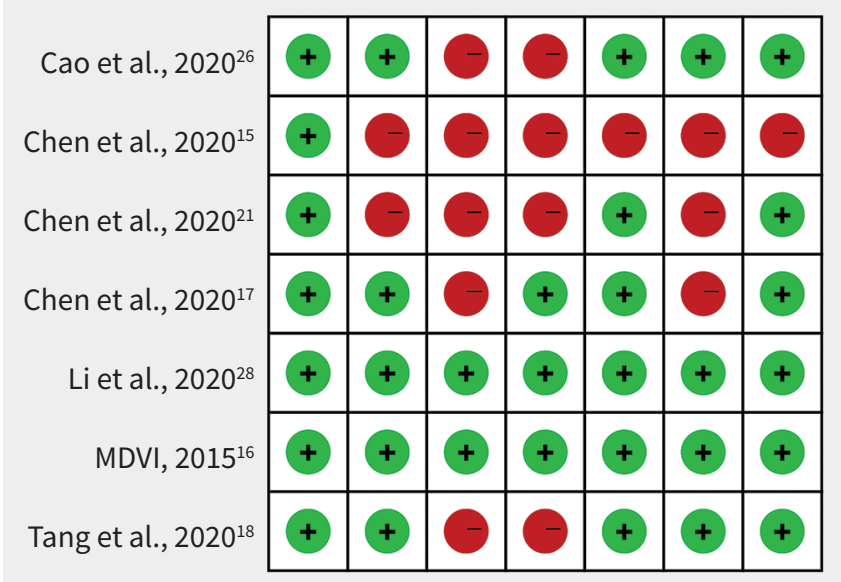

Figure 2: Risk-of-bias assessment for included randomized controlled trials. Note: References 15, 17, 18 and 28 are preprints.

\section{Safety}

The RCT that enrolled 23 patients with nonsevere COVID-19 illness (preprint) ${ }^{28}$ reported that no patients in either the treatment or control groups had diarrhea or decreased appetite (very lowquality evidence; Appendix 5, Supplementary Tables 5 and 6).

\section{Favipiravir}

\section{Efficacy}

One RCT that enrolled 236 patients (preprint) ${ }^{15}$ with mixed-severity COVID-19 illness (88.6\% were nonsevere) compared favipiravir with umifenovir and reported a possible increase in clinical recovery at day 7 with favipiravir (RR 1.18, 95\% Cl 0.95 to 1.48, very low-quality evidence; Appendix 5, Supplementary Table 7). A nonrandomized interventional study that enrolled 80 nonsevere COVID-19 patients ${ }^{14}$ compared favipiravir to lopanivir/ritonavir and reported increased viral clearance at day 7 with favipiravir (HR 3.43, 95\% Cl 1.16 to 10.15 , very low-quality evidence; Appendix 5, Supplementary Tables 7 and 8).
Safety

One RCT that involved 386 patients with influenza ${ }^{16}$ reported inconclusive results regarding whether favipiravir caused diarrhea (risk difference [RD] 3 fewer per 1000 population, 95\% Cl 31 fewer to 64 more per 1000 population, low-quality evidence; Appendix 5, Supplementary Tables 9 and 10).

\section{Interferon- $\alpha$ and interferon- $\beta$}

\section{Efficacy}

One retrospective cohort study that enrolled 70 patients with COVID-19 (preprint) ${ }^{24}$ of mixed severity compared interferon- $\alpha$ plus umifenovir with umifenovir alone and reported on time to viral clearance and length of hospital stay. We performed a multiple linear regression analysis based on the original data set (Appendix 6, available at www.cmaj.ca/lookup/suppl/doi:10.1503/ cmaj.200647/-/DC1). We found that patients receiving interferon- $\alpha$ tended to have a shorter time to viral clearance (MD $4.6 \mathrm{~d}, 95 \% \mathrm{Cl}$ -0.5 to $9.6 \mathrm{~d}$ ) and and a shorter length of hospital stay (MD $4.4 \mathrm{~d}$, $95 \% \mathrm{Cl}-1.5$ to $10.3 \mathrm{~d}$ ) (Appendix 5, Supplementary Tables 11 and 12). However, the quality of evidence was very low because of concurrent use of umifenovir and imprecision of the results.

One retrospective cohort study ${ }^{23}$ and 1 case-control study ${ }^{22}$ that involved a total of 83 patients with MERS of mixed severity provided very low-quality evidence and raised the possibility of decreased mortality with interferon- $\alpha$ (OR $0.23,95 \% \mathrm{Cl} 0.04$ to 1.32) (Appendix 4, Supplementary Figure 5, and Appendix 5, Supplementary Table 14) and interferon- $\beta$ (OR 0.37, 95\% Cl 0.07 to 2.05) (Appendix 4, Supplementary Figure 6, and Appendix 5, Supplementary Table 15).

\section{Safety}

One retrospective cohort study that involved 87 patients with $\mathrm{SARS}^{25}$ provided very low-quality evidence regarding whether interferon- $\alpha$ affects the need for granulocyte colony-stimulating factor in patients with leukopenia (Appendix 5, Supplementary Tables 13 and 14). We found no reports of safety outcomes for interferon- $\beta$.

\section{Lopinavir/ritonavir}

\section{Efficacy}

One RCT that enrolled 199 patients with severe COVID-19 (preprint ${ }^{26}$ compared treatment with lopinavir/ritonavir with no lopinavir/ritonavir treatment and reported on mortality, viral clearance at day 14, mechanical ventilation and length of stay in ICU and hospital. Another RCT compared treatment with lopinavir/ritonavir with no lopinavir/ritonavir treatment in 28 patients with nonsevere COVID-19 (preprint) ${ }^{28}$ and reported on mortality, viral clearance at day 14 , cough alleviation at day 7 , progression from nonsevere to severe illness and fever at day 7 . Because no patients died in the latter RCT, we included only mortality data from the RCT involving patients with severe illness. Another observational study enrolling 120 patients with mixed severity of COVID-19 reported on viral clearance at day 23 (preprint). ${ }^{27}$ We conducted a meta-analysis on viral clearance at day 14 (Appendix 4, Supplementary Figure 7). 
Table 3: Risk-of-bias assessment for included cohort studies using the modified Newcastle-Ottawa scale

\begin{tabular}{|c|c|c|c|c|c|c|c|c|}
\hline Study & $\begin{array}{l}\text { From the } \\
\text { same } \\
\text { population }\end{array}$ & $\begin{array}{l}\text { Assessment } \\
\text { of exposure }\end{array}$ & $\begin{array}{c}\text { Outcome } \\
\text { not present } \\
\text { at start }\end{array}$ & Adjustment & $\begin{array}{l}\text { Assessment } \\
\text { of prognostic } \\
\text { factors }\end{array}$ & $\begin{array}{l}\text { Assessment } \\
\text { of outcome }\end{array}$ & $\begin{array}{l}\text { Adequate } \\
\text { follow-up }\end{array}$ & $\begin{array}{c}\text { Similar } \\
\text { co- } \\
\text { interventions }\end{array}$ \\
\hline $\begin{array}{l}\text { Cai et al., } \\
2020^{14}\end{array}$ & $\begin{array}{l}\text { Definitely } \\
\text { yes }\end{array}$ & $\begin{array}{c}\text { Probably } \\
\text { yes }\end{array}$ & $\begin{array}{l}\text { Definitely } \\
\text { yes }\end{array}$ & $\begin{array}{c}\text { Probably } \\
\text { yes }\end{array}$ & Probably yes & Probably no & $\begin{array}{l}\text { Definitely } \\
\text { yes }\end{array}$ & Probably yes \\
\hline $\begin{array}{l}\text { Lau et al., } \\
2009^{29}\end{array}$ & $\begin{array}{l}\text { Probably } \\
\text { yes }\end{array}$ & $\begin{array}{c}\text { Definitely } \\
\text { yes }\end{array}$ & $\begin{array}{c}\text { Definitely } \\
\text { yes }\end{array}$ & $\begin{array}{c}\text { Probably } \\
\text { yes }\end{array}$ & Definitely yes & $\begin{array}{c}\text { Definitely } \\
\text { yes }\end{array}$ & $\begin{array}{l}\text { Definitely } \\
\text { yes }\end{array}$ & Probably yes \\
\hline $\begin{array}{l}\text { Leong et al., } \\
2004^{30}\end{array}$ & $\begin{array}{l}\text { Definitely } \\
\text { yes }\end{array}$ & $\begin{array}{l}\text { Definitely } \\
\text { yes }\end{array}$ & $\begin{array}{c}\text { Probably } \\
\text { yes }\end{array}$ & $\begin{array}{c}\text { Probably } \\
\text { yes }\end{array}$ & Probably yes & $\begin{array}{l}\text { Definitely } \\
\text { yes }\end{array}$ & $\begin{array}{l}\text { Definitely } \\
\text { yes }\end{array}$ & Probably yes \\
\hline Li et al., $2005^{25}$ & $\begin{array}{c}\text { Probably } \\
\text { yes }\end{array}$ & $\begin{array}{l}\text { Definitely } \\
\text { yes }\end{array}$ & $\begin{array}{c}\text { Probably } \\
\text { yes }\end{array}$ & $\begin{array}{c}\text { Probably } \\
\text { yes }\end{array}$ & Probably no & $\begin{array}{l}\text { Probably } \\
\text { yes }\end{array}$ & $\begin{array}{l}\text { Definitely } \\
\text { yes }\end{array}$ & Probably yes \\
\hline $\begin{array}{l}\text { Muller et al., } \\
2007^{31}\end{array}$ & $\begin{array}{c}\text { Probably } \\
\text { yes }\end{array}$ & $\begin{array}{c}\text { Definitely } \\
\text { yes }\end{array}$ & $\begin{array}{c}\text { Probably } \\
\text { yes }\end{array}$ & $\begin{array}{c}\text { Probably } \\
\text { yes }\end{array}$ & Definitely yes & $\begin{array}{l}\text { Definitely } \\
\text { yes }\end{array}$ & $\begin{array}{l}\text { Definitely } \\
\text { yes }\end{array}$ & Probably yes \\
\hline $\begin{array}{l}\text { Shalhoub et al., } \\
2015^{23}\end{array}$ & $\begin{array}{c}\text { Probably } \\
\text { yes }\end{array}$ & $\begin{array}{l}\text { Definitely } \\
\text { yes }\end{array}$ & $\begin{array}{l}\text { Definitely } \\
\text { yes }\end{array}$ & $\begin{array}{c}\text { Probably } \\
\text { yes }\end{array}$ & Probably no & $\begin{array}{c}\text { Probably } \\
\text { yes }\end{array}$ & $\begin{array}{l}\text { Definitely } \\
\text { yes }\end{array}$ & Probably yes \\
\hline $\begin{array}{l}\text { Zhou et al., } \\
2020 \\
\text { (preprint) }^{24}\end{array}$ & $\begin{array}{l}\text { Definitely } \\
\text { yes }\end{array}$ & $\begin{array}{l}\text { Definitely } \\
\text { yes }\end{array}$ & $\begin{array}{l}\text { Definitely } \\
\text { yes }\end{array}$ & $\begin{array}{c}\text { Probably } \\
\text { yes }\end{array}$ & Probably yes & $\begin{array}{c}\text { Probably } \\
\text { yes }\end{array}$ & $\begin{array}{l}\text { Definitely } \\
\text { yes }\end{array}$ & Probably yes \\
\hline $\begin{array}{l}\text { Yan et al., } 2020 \\
\text { (preprint) }^{27}\end{array}$ & $\begin{array}{c}\text { Probably } \\
\text { yes }\end{array}$ & $\begin{array}{l}\text { Definitely } \\
\text { yes }\end{array}$ & $\begin{array}{c}\text { Probably } \\
\text { yes }\end{array}$ & Probably no & Probably yes & $\begin{array}{c}\text { Probably } \\
\text { yes }\end{array}$ & $\begin{array}{l}\text { Definitely } \\
\text { yes }\end{array}$ & Probably no \\
\hline $\begin{array}{l}\text { Liu et al., } 2020 \\
\text { (preprint) }^{32}\end{array}$ & $\begin{array}{l}\text { Definitely } \\
\text { yes }\end{array}$ & $\begin{array}{l}\text { Definitely } \\
\text { yes }\end{array}$ & $\begin{array}{l}\text { Definitely } \\
\text { yes }\end{array}$ & Probably no & Definitely yes & $\begin{array}{l}\text { Definitely } \\
\text { yes }\end{array}$ & $\begin{array}{l}\text { Definitely } \\
\text { yes }\end{array}$ & Definitely yes \\
\hline $\begin{array}{l}\text { Magagnoli et } \\
\text { al., } 2020 \\
\text { (preprint) }^{19}\end{array}$ & $\begin{array}{l}\text { Definitely } \\
\text { yes }\end{array}$ & $\begin{array}{l}\text { Definitely } \\
\text { yes }\end{array}$ & $\begin{array}{l}\text { Definitely } \\
\text { yes }\end{array}$ & $\begin{array}{c}\text { Probably } \\
\text { yes }\end{array}$ & Definitely yes & $\begin{array}{l}\text { Definitely } \\
\text { yes }\end{array}$ & $\begin{array}{l}\text { Definitely } \\
\text { yes }\end{array}$ & Probably yes \\
\hline $\begin{array}{l}\text { Mahévas et al. } \\
2020 \text { (preprint) }^{20}\end{array}$ & $\begin{array}{l}\text { Definitely } \\
\text { yes }\end{array}$ & $\begin{array}{c}\text { Definitely } \\
\text { yes }\end{array}$ & $\begin{array}{l}\text { Definitely } \\
\text { yes }\end{array}$ & $\begin{array}{c}\text { Probably } \\
\text { yes }\end{array}$ & Probably yes & $\begin{array}{c}\text { Probably } \\
\text { yes }\end{array}$ & $\begin{array}{l}\text { Definitely } \\
\text { yes }\end{array}$ & Probably yes \\
\hline
\end{tabular}

Table 4: Risk-of-bias assessment in the case-control study using the modified Newcastle-Ottawa scale

\begin{tabular}{|l|c|c|c|c|}
\hline Study & $\begin{array}{c}\text { Assessment } \\
\text { of exposure }\end{array}$ & $\begin{array}{c}\text { Cases had developed } \\
\text { the outcome and } \\
\text { controls had not }\end{array}$ & $\begin{array}{c}\text { Selection } \\
\text { of cases }\end{array}$ & $\begin{array}{c}\text { Selection } \\
\text { of controls }\end{array}$ Matching or \\
adjustment
\end{tabular}

For nonsevere COVID-19 patients, lopinavir/ritonavir may provide little or no reduction in viral clearance at day 14 (RD $-0.7 \%, 95 \% \mathrm{Cl}-17.1 \%$ to $20.7 \%$, low-quality evidence; ${ }^{26}$ [preprint $]^{28}$ ). The observational study raised the possibility of increased viral clearance at day 23 with lopinavir/ritonavir treatment, but the study failed to adjust for disease severity, making this result of very low quality (preprint). ${ }^{27}$ Also, there was very low-quality evidence of uncertain effects of lopinavir/ritonavir on cough alleviation at day 7 , progression to severe illness, fever at day 7 and length of hospital stay ${ }^{14}$ (preprint) ${ }^{19}$ (Appendix 5, Supplementary Table 16).

For severe COVID-19 patients, lopinavir/ritonavir may result in a small decrease in mortality (RD 2.4\% fewer deaths, 95\% Cl 5.7\% decrease to $3.1 \%$ increase, low-quality evidence), and reductions in length of ICU stay (RD 5 d shorter, $95 \% \mathrm{Cl} 0$ to $9 \mathrm{~d}$, low-quality evidence) and hospital stay (RD $1 \mathrm{~d}$ shorter, 95\% $\mathrm{Cl} 0$ to $2 \mathrm{~d}$, lowquality evidence $)^{14}$ (Appendix 5, Supplementary Table 17).
Table 5: Baseline risk for patients with severe and nonsevere coronavirus disease 2019

\begin{tabular}{|lcc|}
\hline Intervention & $\begin{array}{c}\text { Patients with } \\
\text { nonsevere } \\
\text { COVID-19 }\end{array}$ & $\begin{array}{c}\text { Patients } \\
\text { with severe } \\
\text { COVID-19 }\end{array}$ \\
\hline Mortality & NA & $10.4 \%^{33}$ \\
\hline Length of hospital stay & $11 \mathrm{~d}^{33}$ & $13 \mathrm{~d}^{33}$ \\
\hline Length of stay in the ICU & $\mathrm{NA}$ & $11 \mathrm{~d}^{26}$ \\
\hline Mechanical ventilation & $\mathrm{NA}$ & $38.7 \%^{33}$ \\
\hline Viral clearance at day 14 & $71.4 \%$ (preprint) ${ }^{28}$ & $56.3 \%^{26}$ \\
\hline Viral clearance at day 7 & $71.4 \%$ (preprint) $^{28}$ & $32.4 \%{ }^{* 26}$ \\
\hline Progressing from nonsevere & $14.3 \%$ (preprint) ${ }^{28}$ & $\mathrm{NA}$ \\
\hline to severe disease & & \\
\hline
\end{tabular}

Note: COVID-19 = coronavirus disease 2019, ICU = intensive care unit, NA = not applicable. *Used day 5 instead of day 7 . 


\section{Safety}

One RCT that involved 194 patients with severe COVID- $19^{26}$ and another RCT that involved 28 patients with nonsevere COVID-19 (preprint) ${ }^{28}$ reported no diarrhea in their control groups. The incidence of diarrhea in the intervention group was $6.0 \%$ (95\% Cl $1.7 \%$ to $10.4 \%,{ }^{26}$ (preprint) ${ }^{28}$ moderate-quality evidence; Appendix 5, Supplementary Tables 16 and 17). The RCT with 194 patients $^{26}$ reported that lopinavir/ritonavir probably increased nausea (MD 9.5\%, 95\% Cl 3.6\% to $15.4 \%$ ) and vomiting (MD $6.3 \%, 95 \% \mathrm{Cl} 1.4 \%$ to $11.2 \%$ ) (both moderate-quality evidence; Appendix 5, Supplementary Tables 16 and 17). This study also reported very low-quality evidence that raised the possibility of an increase in stomach ache (Appendix 5, Supplementary Tables 16 and 17).

\section{Interpretation}

Our systematic review did not find persuasive evidence of benefit for any antiviral agent in patients with COVID-19. We found no direct evidence for treatment using ribavirin in a population of patients with COVID-19, and results from studies evaluating SARS or MERS provided no support for a reduction in mortality with ribavirin treatment. ${ }^{22,29,30}$ We found that interferon did not show a benefit on viral clearance or length of hospital stay in patients with COVID-19.

Hydroxychloroquine and umifenovir failed to show benefit in viral clearance, disease progression or symptom relief in patients with nonsevere COVID-19. In patients with severe COVID-19, treatment using hydroxychloroquine did not show reductions in mortality or mechanical ventilation. Umifenovir appeared to reduce mortality based on 1 observational study with very low-quality evidence. Very low-quality evidence raised the possibility that favipiravir may accelerate clinical recovery relative to umifenovir and accelerate viral clearance relative to lopinavir/ritonavir.

Included RCTs addressed lopinavir/ritonavir in patients with both nonsevere and severe COVID-19. However, the sample size in the RCT that evaluated nonsevere COVID-19 was only 28 patients, resulting in very wide Cls for all outcomes. Based on the RCT evaluating patients with severe COVID-19, it is possible that lopinavir/ritonavir reduced 28-day mortality, length of ICU stay and length of hospital stay, but the evidence was of low quality. Moderate-quality evidence showed substantial increases in gastrointestinal adverse effects with lopinavir/ritonavir.

Adverse effects remain a concern with each of these drugs. Gastrointestinal upset and potential drug-drug interactions are the primary concerns with lopinavir/ritonavir. Hydroxychloroquine and chloroquine widen the QT-interval and based on case reports from the FDA Adverse Event Reporting System database, the US Food and Drug Administration issued a warning about the risk of drug-induced sudden cardiac death associated with use of chloroquine or hydroxychloroquine with or without azithromycin in patients with COVID-19. ${ }^{34}$

Strengths of our review include a study team with methodologic, pharmacologic and clinical expertise from working directly to treat patients with COVID-19, consideration of both direct and indirect evidence, a comprehensive and current literature search, and review of eligibility, risk of bias and data abstraction in duplicate. By using the GRADE approach we focused on the highestquality evidence available and carefully considered indirectness. It also directed us to focus on absolute effects and to produce succinct, informative evidence summaries using table formats.

Since the COVID-19 pandemic began, other efforts have been made to summarize the available evidence about antiviral treatments. Although previous reviews of studies of antiviral treatments in MERS and SARS have been published, they have not been brought together or put in the context of COVID-19 using a rigorous methodologic perspective. ${ }^{35-41}$ For example, the Public Health Agency of Canada (PHAC) published a rapid review on the efficacy and safety of antiviral or antibody treatments for coronavirus. ${ }^{35}$ They included all the known antiviral treatments and antibodies for their potential treatment in coronavirus and searched for all types of studies including preclinical (animal) studies. The methodology of such efforts, including that of PHAC, is limited in 2 aspects. First, they did not use a formal system such as GRADE for rating the certainty of the evidence. In the context of applying evidence from one patient group to another, rating systems need a formal approach to evaluating indirectness - how skeptical we should be when we apply, for instance, evidence from studies evaluating SARS and MERS to COVID-19. Such ratings are crucial for decision-makers to understand evidence credibility. Second, they did not calculate the absolute risk of these agents based on a baseline risk of patients with COVID19 , which limited their application to real-world management of COVID-19. Our review addressed these issues.

Results from ongoing RCTs (preprint) ${ }^{42}$ will certainly increase the quality of the evidence and may provide convincing evidence of benefit that our review did not. Nevertheless, clinicians need guidance at present, and our review serves that purpose.

In vitro and animal studies that evaluated treatment of COVID-19 using remdesivir, chloroquine and hydroxychloroquine have shown inhibitory effects against SARS-CoV-2, which may be promising for antiviral treatment. ${ }^{43-45}$ Investigators have also reported that umifenovir suppresses reproduction of SARS-CoV-2 in cell cultures. ${ }^{46}$ Cell culture and animal studies have provided evidence of activity of ribavirin, high-dose interferon ${ }^{47,48}$ and lopinavir/ritonavir ${ }^{49-51}$ against coronaviruses. Given that each drug has adverse effects, such studies do not provide sufficient rationale for use in humans with COVID-19. ${ }^{52}$

\section{Limitations}

The primary limitation of our review is the very low-quality evidence that is currently available to inform the benefit and harms of available antiviral agents, which suggests uncertainty about their effects. This uncertainty comes primarily from estimates of relative effects but also from estimates of baseline risk in COVID19 that came from single studies with limited sample sizes.

In addition, we restricted our review to interventions in which there was some published evidence. However, given the uncertainty about individual agents, our conclusions of uncertainty about benefit also apply to combinations of these agents. Moreover, combinations of agents are likely to have greater harms than single agents. 


\section{Conclusion}

This review provides evidence to support COVID-19 guideline recommendations. To date, persuasive evidence of important benefit does not exist for any antiviral treatment, although important benefit has not been excluded for each agent. Owing to the very low risk of death in patients with nonsevere COVID-19, antiviral treatment will not result in important reductions to mortality in these patients. Confident administration of any antiviral treatment requires the conduct of RCTs showing patient-relevant benefits.

\section{References}

1. Novel coronavirus (2019-nCoV) situation report - 22. Geneva: World Health Organization; 2020. Available: www.who.int/docs/default-source/coronaviruse /situation-reports/20200211-sitrep-22-ncov.pdf?sfvrsn=fb6d49b1_2 (accessed 2020 Mar. 3).

2. Coronavirus disease 2019 (COVID-19) situation report - 101. Geneva: World Health Organization; 2020. Available: www.who.int/docs/default-source/coronaviruse/ situation-reports/20200430-sitrep-101-covid-19.pdf?sfvrsn=2ba4e093_2 (accessed 2020 May 1).

3. Coronaviridae Study Group of the International Committee on Taxonomy of Viruses. The species Severe acute respiratory syndrome-related coronavirus: classifying 2019-nCoV and naming it SARS-CoV-2. Nat Microbiol 2020;5:536-44.

4. Zhu N, Zhang D, Wang W, et al.; China Novel Coronavirus Investigating and Research Team. A novel coronavirus from patients with pneumonia in China, 2019. NEngl J Med 2020;382:727-33.

5. Lu R, Zhao X, Li J, et al. Genomic characterisation and epidemiology of 2019 novel coronavirus: implications for virus origins and receptor binding. Lancet 2020;395:565-74.

6. Initial public health response and interim clinical guidance for the 2019 novel coronavirus outbreak - United States, December 31, 2019-February 4, 2020 [published erratum in MMWR Morb Mortal Wkly Rep 2020;69:173]; reviewed 2020 Feb. 13. MMWR Morb Mortal Wkly Rep 2020;69:140-6.

7. Clinical management of human infection with COVID-19 (trial guidance version 7), No. 184. Beijing (China): National Health Commission of the People's Republic of China; 2020. Available: www.nhc.gov.cn/xcs/zhengcwj/202003/46c9294a7dfe4cef 80dc7f5912eb1989/files/ce3e6945832a438eaae415350a8ce964.pdf (accessed 2020 Mar. 4).

8. Ye Z, Rochwerg B, Wang Y, et al. Treatment of patients with nonsevere and severe coronavirus disease 2019: an evidence-based guideline. CMAJ 2020 Apr. 29 [Epub ahead of print]. doi: 10.1503/cmaj.200648.

9. Wang Y, Zhang D, Du G, et al. Remdesivir in adults with severe COVID-19: a randomised, double-blind, placebo-controlled, multicentre trial. Lancet 2020 Apr. 29. doi: 10.1016/S0140-6736(20)31022-9.

10. Methodological resources. Ottawa: Evidence Partners. Available: www.evidence partners.com/resources/methodological-resources/ (accessed 2020 Mar. 28).

11. Clinical management of severe acute respiratory infection when COVID-19 is suspected: interim guidance. Geneva: World Health Organization; 2020. Available: www.who.int/publications-detail/clinical-management-of-severe-acute-respiratory -infection-when-novel-coronavirus-(ncov)-infection-is-suspected (accessed 2020 Mar. 17).

12. Skoetz N, Goldkuhle M, van Dalen EC, et al.; GRADE Working Group. GRADE guidelines 27: how to calculate absolute effects for time-to-event outcomes in summary of findings tables and Evidence Profiles. J Clin Epidemiol 2020;118: 124-31.

13. Guyatt GH, Oxman AD, Vist GE, et al.; GRADE Working Group. GRADE: an emerging consensus on rating quality of evidence and strength of recommendations. BMJ 2008;336:924-6.

14. Cai Q, Yang M, Liu D, et al. Experimental treatment with favipiravir for COVID-19: an open-label control study. Engineering (Beijing) 2020 Mar. 18 [Epub ahead of print]. doi: 10.1016/j.eng.2020.03.007.

15. Chen C, Zhang y, Huang J, et al. Favipiravir versus arbidol for COVID-19: a randomized clinical trial [preprint]. medRxiv 2020 Apr. 15. doi: 10.1101/2020.03.17 .20037432 .
16. MDVI. Dose-finding study of favipiravir in the treatment of uncomplicated influenza. ClinicalTrials.gov: NCT01068912; 2014, updated 2015 Nov. 18. Available: https://clinicaltrials.gov/show/NCT01068912 (accessed 2020 Mar. 28).

17. Chen Z, Hu J, Zhang Z, et al. Efficacy of hydroxychloroquine in patients with COVID-19: results of a randomized clinical trial [preprint]. medRxiv 2020 Apr. 10. doi: 10.1101/2020.03.22.20040758.

18. Tang W, Cao Z, Han M, et al. Hydroxychloroquine in patients with COVID-19: an open-label, randomized, controlled trial [preprint]. medRxiv 2020 May 7. doi: 10.1101/2020.04.10.20060558.

19. Magagnoli J, Narendran S, Pereira F, et al. Outcomes of hydroxychloroquine usage in United States veterans hospitalized with COVID-19 [preprint]. medRxiv 2020 Apr. 23. doi: 10.1101/2020.04.16.20065920.

20. Mahevas M, Tran V-T, Roumier M, et al. No evidence of clinical efficacy of hydroxychloroquine in patients hospitalized for COVID-19 infection with oxygen requirement: results of a study using routinely collected data to emulate a target trial [preprint]. medRxiv 2020 Apr. 14. doi: 10.1101/2020.04.10.20060699.

21. Chen J, Liu D, Liu L, et al. A pilot study of hydroxychloroquine in treatment of patients with common coronavirus disease-19 (COVID-19). J Zhejiang Univ 2020;49. doi: 10.3785/j.issn.1008-9292.2020.03.03.

22. Al Ghamdi M, Alghamdi KM, Ghandoora Y, et al. Treatment outcomes for patients with Middle Eastern Respiratory Syndrome Coronavirus (MERS CoV) infection at a coronavirus referral center in the Kingdom of Saudi Arabia. BMC Infect Dis 2016;16:174.

23. Shalhoub S, Farahat F, Al-Jiffri A, et al. IFN- $\alpha 2$ a or IFN- $\beta 1$ a in combination with ribavirin to treat Middle East respiratory syndrome coronavirus pneumonia: a retrospective study. J Antimicrob Chemother 2015;70:2129-32.

24. Zhou Q, Wei X-S, Xiang X, et al. Interferon- $\alpha 2 b$ treatment for COVID-19 [preprint]. medRxiv 2020 Apr. 10. doi: 10.1101/2020.04.06.20042580.

25. Li J, Wu H, Huang Z, et al. Clinical study of interferon- $\alpha$ in the treatment of severe acute respiratory syndrome. Clinical Medicine of China 2005;21:109-10.

26. Cao B, Wang $Y$, Wen $D$, et al. A trial of lopinavir-ritonavir in adults hospitalized with severe COVID-19. N Engl J Med 2020;382:1787-99.

27. Yan D, Liu X-y, Zhu Y-n, et al. Factors associated with prolonged viral shedding and impact of lopinavir/ritonavir treatment in patients with SARS-CoV-2 infection [preprint]. medRxiv 2020 Mar. 30. doi: 10.1101/2020.03.22.20040832.

28. Li Y, Xie Z, Lin W, et al. An exploratory randomized, controlled study on the efficacy and safety of lopinavir/ritonavir or arbidol treating adult patients hospitalized with mild/moderate COVID-19 (ELACOI) [preprint]. medRxiv 2020 Apr. 15. doi: 10.1101/2020.03.19.20038984.

29. Lau EH, Cowling BJ, Muller MP, et al. Effectiveness of ribavirin and corticosteroids for severe acute respiratory syndrome. Am J Med 2009;122:1150.e11-21.

30. Leong HN, Ang B, Earnest A, et al. Investigational use of ribavirin in the treatment of severe acute respiratory syndrome, Singapore, 2003. Trop Med Int Health 2004;9:923-7.

31. Muller MP, Dresser L, Raboud J, et al.; Canadian SARS Research Network. Adverse events associated with high-dose ribavirin: evidence from the Toronto outbreak of severe acute respiratory syndrome. Pharmacotherapy 2007;27:494-503.

32. Liu Q, Fang X, Tian L, et al. The effect of arbidol hydrochloride on reducing mortality of COVID-19 patients: a retrospective study of real world data from three hospitals in Wuhan [preprint]. medRxiv 2020 Apr. 17. doi: 10.1101/2020.04.11.20056523.

33. Guan W-j, Ni Z-y, Hu Y, et al. Clinical characteristics of coronavirus disease 2019 in China. N Engl J Med 2020;382:1708-20.

34. FDA drug safety communication: FDA cautions against use of hydroxychloroquine or chloroquine for COVID-19 outside of the hospital setting or a clinical trial due to risk of heart rhythm problems - Does not affect FDA-approved uses for malaria, lupus, and rheumatoid arthritis [safety announcement]. Rockville (MD): US Food and Drug Administration; 2020 Apr. 24. Available: www.fda.gov/media/137250/ download (accessed 2020 May 1).

35. Rios P, Radhakrishnan A, Antony J, et al. Effectiveness and safety of antiviral or antibody treatments for coronavirus: a rapid review [preprint]. medRxiv 2020 Mar. 25. doi: 10.1101/2020.03.19.20039008.

36. Gross AE, Bryson ML. Oral ribavirin for the treatment of noninfluenza respiratory viral infections: a systematic review. Ann Pharmacother 2015;49:1125-35.

37. Momattin H, Al-Ali AY, Al-Tawfiq JA. A systematic review of therapeutic agents for the treatment of the Middle East respiratory syndrome coronavirus (MERS-CoV). Travel Med Infect Dis 2019;30:9-18. 
38. Morra ME, Van Thanh L, Kamel MG, et al. Clinical outcomes of current medical approaches for Middle East respiratory syndrome: a systematic review and meta-analysis. Rev Med Virol 2018;28:e1977.

39. Soares-Weiser K, Thomas S, Thomson G, et al. Ribavirin for Crimean-Congo hemorrhagic fever: systematic review and meta-analysis. BMC Infect Dis 2010;10:207.

40. Stockman LJ, Bellamy R, Garner P. SARS: systematic review of treatment effects. PLoS Med 2006;3:e343.

41. Momattin H, Mohammed K, Zumla A, et al. Therapeutic options for Middle East respiratory syndrome coronavirus (MERS-CoV) - possible lessons from a systematic review of SARS-CoV therapy. Int J Infect Dis 2013;17:e792-8.

42. Belhadi D, Peiffer-Smadja N, Lescure F-X, et al. A brief review of antiviral drugs evaluated in registered clinical trials for COVID-19 [preprint]. medRxiv 2020 Mar. 27. doi: 10.1101/2020.03.18.20038190

43. Wang $M$, Cao R, Zhang $L$, et al. Remdesivir and chloroquine effectively inhibit the recently emerged novel coronavirus (2019-nCoV) in vitro. Cell Res 2020;30:269-71.

44. Liu J, Cao R, Xu M, et al. Hydroxychloroquine, a less toxic derivative of chloroquine, is effective in inhibiting SARS-CoV-2 infection in vitro. Cell Discov 2020;6:16.

45. Yao X, Ye F, Zhang M, et al. In vitro antiviral activity and projection of optimized dosing design of hydroxychloroquine for the treatment of severe acute respiratory syndrome coronavirus 2 (SARS-CoV-2). Clin Infect Dis 2020 Mar. 9 [Epub ahead of print]. pii: ciaa237. doi: 10.1093/cid/ciaa237.
46. Khamitov RA, Loginova Sla, Shchukina VN, et al. Antiviral activity of arbidol and its derivatives against the pathogen of severe acute respiratory syndrome in the cell cultures [article in Russian]. Vopr Virusol 2008;53:9-13.

47. Kindler E, Thiel V, Weber F. Chapter seven - Interaction of SARS and MERS coronaviruses with the antiviral interferon response. In: Ziebuhr, J, editor. Advances in Virus Research. Vol. 96. Cambridge (MA): Academic Press; 2016: 219-43.

48. Hart BJ, Dyall J, Postnikova E, et al. Interferon- $\beta$ and mycophenolic acid are potent inhibitors of Middle East respiratory syndrome coronavirus in cellbased assays. J Gen Virol 2014;95:571-7.

49. Chan JF, Yao Y, Yeung ML, et al. Treatment with lopinavir/ritonavir or interferon-1 $\beta \mathrm{b}$ improves outcome of MERS-CoV infection in a nonhuman primate model of common marmoset. J Infect Dis 2015;212:1904-13.

50. Chu CM, Cheng VC, Hung IF, et al.; HKU/UCH SARS Study Group. Role of lopinavir/ ritonavir in the treatment of SARS: initial virological and clinical findings. Thorax 2004;59:252-6.

51. Chen F, Chan KH, Jiang J, et al. In vitro susceptibility of 10 clinical isolates of SARS coronavirus to selected antiviral compounds. J Clin Virol 2004;31:69-75.

52. Kalil AC. Treating COVID-19 - Off-label drug use, compassionate use, and randomized clinical trials during pandemics. JAMA 2020 Mar. 4 [Epub ahead of print]. doi: 10.1001/jama.2020.4742.
Competing interests: Ning Shen is an investigator in a clinical trial evaluating the effect of hydroxychloroquine in patients with coronavirus disease 2019 that is funded by the Peking University Health Science Center. No other competing interests were declared.

This article has been peer reviewed.

Affiliations: Department of Pharmacy (W. Liu, Zhou, F. Liu, Li, He, Wu, Q. Zhang, Tang, Du, Ying, Xu, Y. Zhang, Li, Zhai), Peking University Third Hospital, Beijing, China; Institute for Drug Evaluation (Zhai, F. Liu), Departments of Pharmacy Administration and Clinical Pharmacy (Wu, Du, Y. Zhang), and Respiratory and Critical Care Medicine (Shen), Peking University Health Science Center, Beijing, China; College of Pharmacy (Chen), University of Nebraska Medical Center, Omaha, Neb.; Department of Health Research Methods, Evidence and Impact (Ye, Ibrahim, Guyatt), McMaster University, Hamilton, Ont.; Department of Pharmacy (Gong, J. Liu), Tongji Hospital, Tongji Medical College, Huazhong University of Science and Technology, Wuhan, Hubei, China; DeGroote Institute for Pain Research and Care (Couban), McMaster University, Hamilton, Ont.; Pharmacy Department (Y. Li), First Hospital of Shanxi Medical University, Taiyuan, Shanxi, China
Contributors: Wei Liu, Pengxiang Zhou, Ken Chen, Zhikang Ye, Fang Liu, Xiaotong Li, Na He, Ning Shen, Suodi Zhai and Gordon Guyatt contributed to the conception or design of the study. Wei Liu, Pengxiang Zhou and Ken Chen drafted the manuscript. Wei Liu, Pengxiang Zhou, Ken Chen, Zhikang Ye, Fang Liu, Xiaotong Li, Na He, Ziyang Wu, Qi Zhang, Xuepeng Gong, Qiyu Tang, Xin Du, Yingqiu Ying, Xiaohan Xu, Yahui Zhang, Jinyu Liu, Yun Li, Ning Shen, Rachel Couban, Quazi Ibrahim, Gordon Guyatt and Suodi Zhai acquired, analyzed or interpreted the data. All of the authors revised the manuscript critically for important intellectual content, gave final approval of the version to be published and agreed to be accountable for all aspects of the work. Wei Liu, Pengxiang Zhou and Ken Chen contributed equally to this work.

Funding: Ken Chen is sponsored by the China Scholarship Council.

Data sharing: All of our data are available as tables and figures in the article or in the appendices.

Accepted: May 8, 2020

Correspondence to: Suodi Zhai, zhaisuodi@163.com 